\title{
59 昇降機能付車椅子の開発
}

今井 勝, 森 万希子, 名取 忍, 小川愛一郎, 池田正樹, 宮川政昭 (医療 法人愛政会保土ケ谷腎クリニック），石田清治（新日本空調新事業開発部）

〔開発曰的〕病院および診療所などで，患者の搬送 時に使用している車椅子には用途に灾じた各種の車椅 子があるが，患者がベッドや診察台から車椅子に，逆 に車椅子からべッドや診療台に移動する際には，介護 者が必要であり，患者の状態によっては介護者の負担 が大きいのが現状である。これは在宅においても同様 である，われわれはこのような問題点に着目し，車椅 子搬送時における患者移動時の介護者の負担軽減と, 患者の安全な移動を目的とし，全体を上下方向に移動 可能とした車椅子を開発したので報告する。

[基本的要求仕様〕 車椅子の基本的仕様を以下に述 べる. a, 昇降装置の取り扱いが簡単で安全であるこ と. b, 舁降装置は軽量, シンプル, 安価であること. $c$, 异降装置は從来用いられる車椅子にオプションと して追加できること．d，折り畳み可能な車椅子の場 合，昇降装置はその機能を妨げないこと，e，患者が 搬送される時の車椅子の着座位置は床から約 $450 \mathrm{~mm}$ であるが，患者がベッドや診察台から車椅子に，逆に
車椅子からベッドや診察台に移動する際にはこれを最 高で $650 \mathrm{~mm}$ の位置まで上昇できることとした。なお 高さを $650 \mathrm{~mm}$ としたのは患者の立位のしやすさおよ び介護者の負担を軽減し患者自らが着座できる高さと して設定したものである。

〔昇降装置の概要〕最む一般的に用いられている車 椅子の両車輪の内側の車軸之平行な金属部分にジャッ キを2つ設置し，2つのジャッキを連結するためのジャッ キ朝を設け，そのジャッキ軸の中央に手回しハンドル を付け，左右の回転にて車椅子が昇降機能を持つよう に設計した。

〔結語〕 (1)昇降機能付き車椅子は乗降の際にも重心 が不安定にならず安全な患者移動が可能であった。 (2) 本車椅子は昇降機能付きなため乗降時の介護者負担が 軽滅された。(3)本車椅子の構造は非常にシンプルなた め安佃に製作でき。しかる軽量であることなどが確認 された。

\section{0 血液ポンプ/インフュージョンポンプの連動を可能しした 心筋保護液注入用ポンプの試作 \\ 南茂（福岡大病院手術部）, 田代 忠, 木村道生（福岡大病院心臟血管外科）, 三澤和義（泉工医科工業開発部）}

心筋保護法として高K血液心筋保護法が一般的にな っている. 人工心肺血と Fremes 液などの高 K 液を 混合する方法汃用いられているが，血液希釈，高血喏 などの問題点がある。これらを解決する方法として, 人工心肺血に $\mathrm{KCl}$ を混合する方法が報告されている が，心筋保護の血液流量を变化させると添加 $\mathrm{K}^{+}$濃度 を换算し $\mathrm{KCl}$ の注入量を手動で調整する必要があり, 操作が複雑で $\mathrm{K}^{+}$濃度の安定も得られない。そこでわ れわれは，血液ポンプ（以下，BP）とインフュージョ ンポンプ（以下，IP）の連動を可能とした心筋保護 液注入用ポンプを試作しその基本性能について検証し たので報告する。

〔装置〕メラ透析用血液ポンプKBM-1をベースに, BP のタコジェネレータ出力ょり $\mathrm{BP} / \mathrm{IP}$ 比が $100: 1$, $333: 1$ となるように定量比設定回路を組み込み $\mathrm{BP}$ と IPが連動するように構成した。また，KBM-1の BP ギア比を $1 / 50$ から $1 / 36$ に変更し $450 \mathrm{ml} / \mathrm{min}$ 以上の 流量を可能にした.

〔方法〕 BP/IP 比が $100: 1$ と $333: 1$ の時の IP 流
量を，BP 流量 50，100，150，200，300，400 および $500 \mathrm{~m} l / \mathrm{min}$ 時にそれぞれ測定し理論值との相関を求 めた。 また, $\mathrm{BP}$ (生理食塩水) と IP ( $\mathrm{KCl}: 2 \mathrm{mEq} /$ $\mathrm{ml} l)$ の混合液 $\mathrm{K}^{+}$濃度を各流量比および各流量におい て測定した。

〔結果〕全 BP 流量に㧍ける IP 流量は, $100: 1$ ( $\mathrm{n}=$ 35) で $\mathrm{y}=1.012 \mathrm{x}-0.010, \mathrm{R}^{2}=1(\mathrm{p}<0.001), 333$ : $1(\mathrm{n}=35)$ で $\mathrm{y}=1.030 \mathrm{x}-0.014, \mathrm{R}^{2}=1(\mathrm{p}<0.001)$ であった. 混合 $\mathrm{K}^{+}$濃度 $(\mathrm{mEq} / \mathrm{L})$ は, $100: 1(20$ $+/-0.5 \mathrm{mEq} / \mathrm{L})$ で $21.7 \pm 0.55,333: 1(6+/-0.5$ $\mathrm{mEq} / \mathrm{L})$ で $6.3 \pm 0.21$ であった.

〔結論〕 $\mathrm{BP} / \mathrm{IP}$ 比から求めたIPの理論值と実測值 には高い相関関係が得られ, 設定した BP/IP 比をも って正確に連動できた。混合液 $\mathrm{K}^{+}$濃度は理論值より 若干高値であったが, 各流量での $\mathrm{K}^{+}$濃度はほぼ一定 であったことから，BP流量の䛊差などの他因子が影 響したものと推測される. 今回試作した $\mathrm{CP}$ 液注入用 ポンプの基本性能は十分に臨床使用できるものと考え る. 